\title{
PENGARUH CORPORATE SOCIAL RESPONSIBILITY (CSR) TERHADAP PROFITABILITAS PADA PERUSAHAAN INDUSTRI PENGHASIL BAHAN BAKU SEKTOR PERKEBUNAN YANG TERDAFTAR DI BURSA EFEK INDONESIA PERIODE 2013 - 2017
}

\author{
${ }^{1)}$ Heru Satria Rukmana, ${ }^{2)}$ Muhamad Ikhbal Saputra \\ ${ }^{1)}$ Dosen Program Studi Manajemen, STIE Dewantara \\ J1. Raya Pemda Bojong Depok Baru III, Karadenan, Cibinong, Bogor, Jawa Barat 16913,Indonesia \\ Email: heru.satria@dewantara.ac.id \\ ${ }^{2)}$ Alumni Program Studi Manajemen, STIE Dewantara \\ J1. Raya Pemda Bojong Depok Baru III, Karadenan, Cibinong, Bogor, Jawa Barat 16913,Indonesia \\ Email: muhamadikhbalsaputra@gmail.com
}

\begin{abstract}
The purpose of this study was to determine the effect of Corporate Social Responsibility (CSR) on company profitability. The independent variable in this study is the disclosure of Corporate Social Responsibility (CSR) as measured by indicators of the global reporting initiative (GRI) such as CSR-economy, CSR-environment, and CSR-social. The dependent variable in this study is the company's profitability measured by using net profit margin (NPM). This research is a clause study. The sampling technique was carried out using the purposive sampling method with the criteria of plantation companies listed on the Indonesia Stock Exchange which published a complete financial report for the 2013-2017 period. The data analysis technique was carried out by the method of Multiple Linear Regression using SPSS 23 program tools. The results of this study are CSR-economic disclosure has no effect on NPM, CSR-environmental disclosure has a negative effect on NPM, and CSR-social disclosure has no effect on NPM, CSR-economic disclosure, CSR-environment, CSR-social has a positive effect on NPM.
\end{abstract}

Keywords: Corporate Social Responsibility, CSR-Economics, CSR-Environment, CSRSocial, NPM.

\begin{abstract}
ABSTRAK
Tujuan penelitian ini untuk mengetahui pengaruh Corporate Social Responsibility (CSR) terhadap profitabilitas perusahaan. Variabel independen dalam penelitian ini adalah pengungkapan Corporate Social Responsibility (CSR) yang diukur dengan indikator-indikator globar reporting initiative (GRI) seperti CSR-ekonomi, CSR-lingkungan, dan CSR-sosial. Variabel dependen dalam penelitian ini adalah profitabilitas perusahaan yang diukur dengan menggunakan net profit margin (NPM). Penelitian ini merupakan penelitian kausalitas. Teknik sampling dilakukan dengan metode purposive sampling dengan kriteria perusahan pekebunan yang terdaftar di Bursa Efek Indonesia yang mempublikasikan laporan keuangan secara lengkap periode 2013-2017. Teknik analisis data dilakukan dengan metode Regresi Linear Berganda dengan mengunakan alat bantu program SPSS 23. Hasil dari penelitian ini adalah pengungkapan CSR-ekonomi tidak berpengaruh terhadap NPM, pengungkapan CSR-lingkunga berpengaruh negatif terhadap NPM, dan pengungkapan CSR-sosial tidak berpengaruh terhadap NPM, pengungkapan CSR-ekonomi, CSR-lingkungan, CSR-sosial berpengaruh positif terhadap NPM.
\end{abstract}

Kata kunci: Corporate Social Responsibility, CSR-Ekonomi, CSR-Lingkungan, CSR-Sosial, NPM.

\begin{tabular}{llll}
\hline 1. & PENDAHULUAN & tanggungjawab sosial perusahaan kepada \\
1.1 Latar Belakang & masyarakat. Hal ini sesuai dengan \\
Corporate Social & Responsibility & pernyataan Beny (2012:6) dalam \\
(selanjutnya dinyatakan dengan CSR) & memberikan tanggung jawabnya berupa \\
merupakan $\quad$ wujud & pelaksanaan & materi seperti uang, peralatan, atau hadiah
\end{tabular}


lainnya kepada komunitas, organisasi atau individu di wilayah di mana perusahaan tersebut beroperasi. Konsep CSR pertama kali dikemukakan oleh Howard R. Bowen pada tahun 1953. Awalnya CSR dilandasi oleh kegiatan yang bersifat 'filantropi' yakni dorongan kemanusiaan yang bersumber dari norma dan etika universal untuk menolong sesama dan memperjuangkan perataan sosial.

Masyarakat pada saat ini lebih pintar dalam memilih setiap produk yang akan mereka beli/konsumsi. Masyarakat cenderung untuk memilih produk yang diproduksi atau dihasilkan oleh perusahaan yang peduli terhadap lingkungan dan social, atau perusahaan yang melaksanakan CSR. Survei yang dilakukan Booth-Harris Trust Monitor pada tahun 2001 menyatakan bahwa mayoritas konsumen akan meninggalkan suatu produk dari suatu perusahaan yang mempunyai citra buruk atau memilki citra negative di masyarakat. Banyak manfaat yang diperoleh perusahaan dengan pelaksanan tanggung jawab social, atau corporate social responsibility, antara lain produk yang dihasilkan semakin diminati oleh konsumen dan perusahaan disukai oleh investor. Selain itu, Corporate social responsibility dapat digunakan sebagai alat marketing model baru bagi perusahaan bila itu dilaksanakan secara jangka panjang atau berkelanjutan. Untuk melaksanakan berbagai kegiatan CSR berarti perusahaan harus mengeluarkan sejumlah biaya, dan biaya pada akhirnya akan menjadi beban yang harus ditanggung oleh perusahaan sehingga mengurangi pendapatan, dan mengakibatkan tingkat profit perusahaan akan mengalami penurunan. Akan tetapi, sisi baik dengan melaksanakan kegiatan CSR, citra perusahaan akan semakin baik di mata konsumen, sehingga loyalitas konsumen akan semakin tinggi.

Dari uraian diatas dapat memberikan bukti bahwa terdapat suatu hubungan antara praktik kegiatan CSR, dengan strategi perusahaan dalam meningkatkan profitabilitas bagi perusahaan. Dengan perusahaan melakukan praktik CSR, secara tidak langsung hal tersebut menjadi salah satu kegiatan promosi yang dilakukan perusahaan terhadap masyarakat dan para investor.

Berdasarkan latar belakang masalah diatas maka peneliti ingin mengetahui lebih lanjut tentang pengaruh CSR terhadap profitabiltas perusahaan.

\subsection{Rumusan Masalah}

maka rumusan masalah penelitian ini adalah:

1. Apakah CSR-ekonomi dalam Corporate Social Responsibility berpengaruh terhadap profitabilitas pada perusahaan perkebunan yang terdaftar di Bursa Efek Indonesia periode 2013-2017?

2. Apakah CSR-lingkungan dalam Corporate Social Responsibility berpengaruh terhadap profitabilitas pada perusahaan perkebunan yang terdaftar di Bursa Efek Indonesia periode 2013-2017?

3. Apakah CSR-sosial dalam Corporate Social Responsibility berpengaruh terhadap profitabilitas pada perusahaan perkebunan yang terdaftar di Bursa Efek Indonesia periode 2013-2017?

4. Apakah CSR-ekonomi, CSRlingkungan dan CSR-sosial dalam Corporate Social Responsibility berpengaruh terhadap profitabilitas pada perusahaan perkebunan yang terdaftar di Bursa Efek Indonesia periode 2013-2017?

\subsection{Tujuan Masalah}

Berdasarkan latar belakang yang telah diuraikan sebelumnya, maka tujuan masalah penelitian ini adalah:

1. Mengertahui pengaruh CSR-ekonomi dalam Corporate Social Responsibility terhadap profitabilitas pada perusahaan 
perkebunan yang terdaftar di Bursa Efek Indonesia periode 2013-2017.

2. Mengetahui pengaruh CSR-lingkungan dalam Corporate Social Responsibility terhadap profitabilitas pada perusahaan perkebunan yang terdaftar di Bursa Efek Indonesia periode 2013-2017.

3. Mengetahui pengaruh CSR-sosial dalam Corporate Social Responsibility berpengaruh terhadap profitabilitas pada perusahaan perkebunan yang terdaftar di Bursa Efek Indonesia periode 2013-2017.

4. Mengetahui pengaruh CSR-ekonomi, CSR-lingkungan dan CSR-sosial dalam Corporate Social Responsibility terhadap profitabilitas pada perusahaan perkebunan yang terdaftar di Bursa Efek Indonesia periode 2013-2017.

\section{TINJAUAN PUSTAKA}

\subsection{Landasan Teori}

\subsubsection{Pengertian Corporate Social Responsibility (CSR)}

Corporate Social Responsibility (selanjutnya dinyatakan dengan CSR) merupakan wujud pelaksanaan tanggungjawab sosial perusahaan kepada masyarakat. Hal ini sesuai dengan pernyataan Beny (2012:6) dalam memberikan tanggung jawabnya berupa materi seperti uang, peralatan, atau hadiah lainnya kepada komunitas, organisasi atau individu di wilayah di mana perusahaan tersebut beroperasi. Konsep CSR pertama kali dikemukakan oleh Howard R. Bowen pada tahun 1953. Awalnya CSR dilandasi oleh kegiatan yang bersifat 'filantropi' yakni dorongan kemanusiaan yang bersumber dari norma dan etika universal untuk menolong sesama dan memperjuangkan perataan sosial.

\subsubsection{Pedoman Laporan Keberlanjutan Global Reporting Initiative}

Global Reporting Initiative (GRI) merupakan organisasi nonprofit yang memajukan ekonomi, keberlanjutan lingkungan dan sosial, GRI menyajikan semua perusahaan dan organisasi dengan kerangka pelaporan keberlanjutan yang komprehensif dan banyak digunakan diseluruh dunia. Laporan keberlanjutan adalah praktik pengukuran, pengungkapan dan upaya akuntabilitas dari kinerja organisasi dalam mencapai tujuan pembangunan keberlanjutan kepada para pemangku kepentingan baik internal maupun eksternal.

Kerangka pelaporan GRI ditunjukan sebagai sebuah kerangka yang dapat diterima umum dalam melaporkan kinerja ekonomi, lingkungan dan sosial dari organisasi.

\subsubsection{Net Profit Margin (NPM)}

Net Profit Margin menhitung sejauh mana kemampuan perusahaan menghasilkan laba bersih pada tingkat penjualan tertentu. Rasio ini bisa dilihat secara langsung pada analisis common size untuk laporan laba rugi. Rasio ini bisa diinterprestasikan juga sebagai kemampuan perusahaan menekan biaya-biaya (ukuran efisiensi) di perusahaan pada periode tertentu.

Net Profit Margin (NPM), merupakan rasio yang digunakan untuk mengukur margin laba atas penjualan, rasio ini akan menggambarkan penghasilan bersih perusahaan berdasarkan total penjualan. Pengukuran rasio dapat dilakukan dengan cara membandingkan laba bersih setelah pajak dengan penjualan bersih. Formulasi dari net profit margin adalah sebagai berikut (Kasmir, 2008: 200). 


\subsection{Kerangka Pemikiran}

Berdasarkan hubungan antar variabel maka gambar kerangka pemikirannya adalah sebagai berikut :

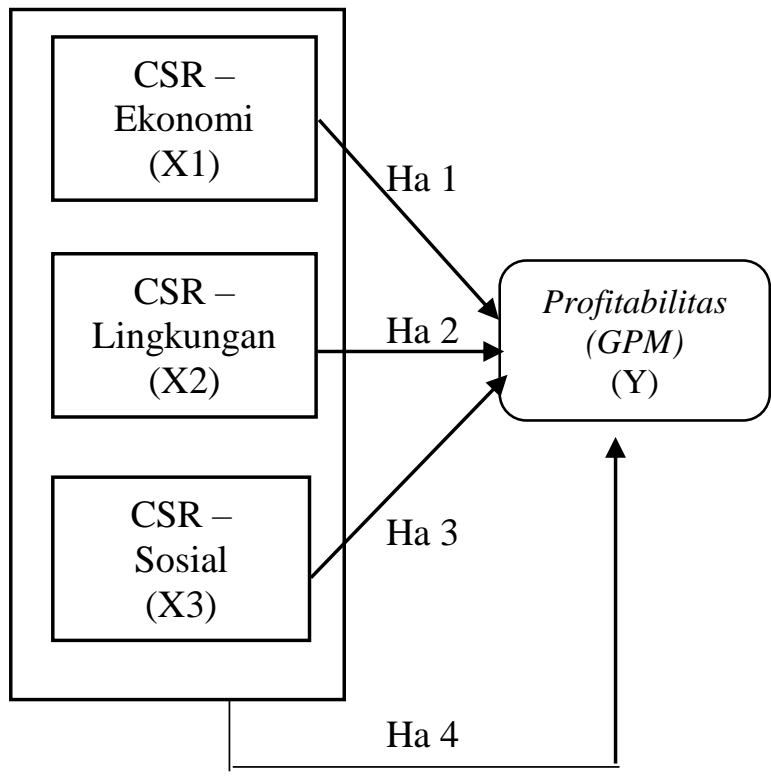

\section{Gambar 1. Kerangka Pemikiran}

\section{METODE PENELITIAN}

\subsection{Jenis Penelitian}

Penelitian ini termasuk ke dalam penelitian kausalitas. Lokasi penelitian ini adalah Bursa Efek Indonesia. Pada Bursa Efek Indonesia penelitian mengambil dan mengelola dana emiten 5 (lima) perusahaan yang bergerak dalam industri penghasil bahan baku sektor perkebunan, yaitu laporan keuangan dari tahun 2013 sampai dengan 2017.

\subsection{Variabel Penelitian}

Dalam penelitian ini terdapat 4 (empat) variabel yang terdiri dari 3 (tiga) variabel independen dan 1 (satu) variabel dependen yang akan diteliti yaitu :

1. Variabel Independen (Bebas)
a. CSR-Ekonomi (X1)
b. CSR-Lingkungan (X2)
c. CSR-Sosial (X3)

2. Variabel Dependen (Terikat)

a. Net Profit Margin (NPM) (Y)

\subsection{Lokasi dan Waktu Penelitian}

Lokasi penelitian ini adalah Bursa Efek Indonesia. Pada Bursa Efek Indonesia penelitian mengambil dan mengelola dana emiten 5 (lima) perusahaan yang bergerak dalam industri penghasil bahan baku sektor perkebunan, yaitu laporan keuangan dari tahun 2013 sampai dengan 2017.

Penelitian ini dilakukan tanpa melakukan observasi langsung ke perusahaan, melainkan sumber data sekunder yang diperoleh berasal dari website masing-masing perusahaan dan Bursa Efek Indonesia (BEI) dengan menggunakan media website (www.idx.id).

Waktu penelitian ini dilakukan dari bulan Agustus sampai dengan Desember 2018.

\subsection{Objek Penelitian}

Objek peneltian ini adalah laporan keuangan perusahaan-perusahaan industri penghasil bahan baku sektor perkebunan yang merupakan perusahaan go public yang terdaftar dalam Bursa Efek Indonesia. Dalam penelitian ini penulis melakukan penelitian seberapa pengaruh Corporate Social Responsibility terhadap profitabilitas perusahaan industri bahan baku sektor perkebunan dari tahun 2013 sampai dengan 2017.

\subsection{Populasi dan Sampel}

\subsubsection{Populasi}

Dalam penelitian ini yang dijadikan populasi adalah seluruh perusahaan industri penghasil bahan baku sektor perkebunan yang terdaftar di Bursa Efek Indonesia (BEI).

\subsubsection{Sampel}

Dalam penelitian ini perusahaan yang menjadi sampel dipilih berdasarkan Purposive Sampling. Didapati 5 (lima) perusahaan yang dijadikan sampel perusahaan yang menerapkan Corporate Social Responsibility (CSR), maka sampel penelitian ini adalah data laporan keuangan 
perusahaan industri bahan baku sektor perkebunan yang go public dan terdaftar di Bursa Efek Indonesia (BEI). Sampel dalam penelitian ini dapat dilihat pada tabel berikut:

Tabel 1. Sampel Penelitian

\begin{tabular}{|c|c|l|}
\hline No & Kode & \multicolumn{2}{|c|}{ Nama Perusahaan } \\
\hline 1 & DSNG & $\begin{array}{l}\text { PT DHARMA SATYA } \\
\text { NUSANTARA Tbk }\end{array}$ \\
\hline 2 & LSIP & $\begin{array}{l}\text { PT PP LONDON } \\
\text { SUMATRA } \\
\text { INDONESIA Tbk }\end{array}$ \\
\hline 3 & SGRO & $\begin{array}{l}\text { PT } \quad \text { SAMPOERNA } \\
\text { ARGO Tbk }\end{array}$ \\
\hline 4 & SIMP & $\begin{array}{l}\text { PT SALIM IVOMAS } \\
\text { PRATAMA Tbk }\end{array}$ \\
\hline 5 & SMAR & $\begin{array}{l}\text { PT SIRNA ARGO } \\
\text { RESOURCES AND } \\
\text { TECHNOLOGY Tbk }\end{array}$ \\
\hline
\end{tabular}

Sumber : www.idx.co.id tahun 2018

\subsection{Teknik Analisis Data}

\subsubsection{Teknik Asumsi Klasik}

Uji asumsi klasik digunakan untuk menguji apakah model regresi benar-benar dapat digunakan untuk mengetahui pengaruh CSR terhadap profitabilitas dan benar-benar dapat dijadikan sebagai dasar penelitian (representative). Uji asumsi klasik terdiri dari: uji normalitas, uji autokorelasi, uji multikolinearitas, dan uji heterokedasitas. Model regresi akan menghasilkan estimator yang baik jika memenuhi asumsi klasik yaitu berdistribusi normal, bebas autokorelasi, multikolinearitas dan heterokedastisitas.

\subsubsection{Uji Analisis Regresi Linier Berganda}

Hasil dari analisis regresi adalah berupa koefisien untuk masing-masing variabel independen. Persamaan regresi linier berganda dalam penelitian ini adalah sebagai berikut :

PROF $=\alpha+\beta 1$ CSRekonomi $+\beta 2$ CSRlingkungan $+\beta 3$ CSRsosial $+\mathrm{e}$
Keterangan:

PROF $=$ Profitabilitas

$\alpha=$ Konstanta

$\beta 1=$ Koefisien regresi dari CSRekonomi

$\beta 2=$ Koefisien regresi dari CSRlingkungan

$\beta 3=$ Koefisien regresi dari CSRsosial

$\mathrm{e} \quad=$ Erorr

\subsubsection{Uji Hipotesis}

\subsubsection{Koefisien Determinasi}

Menurut Ghozali (2012: 97) koefisien determinasi $\left(\mathrm{R}_{2}\right)$ merupakan alat mengukur seberapa jauh kemampuan model dalam menerangkan variasi variabel dependen.

\subsubsection{Uji F (Silmutan)}

Uji statistik $F$ pada dasarnya menunjukkan apakah semua variabel independen atau bebas yang dimasukkan dalam model mempunyai pengaruh secara bersama-sama terhadap variabel dependen/terikat. Uji ini dilakukan dengan membandingkan signifikansi $F$ hitung dengan ketentuan:

a. Jika $\mathrm{F}$ hitung $\leq \mathrm{F}$ tabel pada $\alpha 0.05$, maka Ha ditolak.

b. Jika $\mathrm{F}$ hitung $>\mathrm{F}$ tabel pada $\alpha 0.05$, maka Ha diterima.

\subsubsection{Uji t (Parsial)}

Uji statistik $t$ pada dasarnya menunjukkan seberapa jauh pengaruh satu variabel penjelas/independen secara individual dalam menerangkan variabel 48 dependen. Uji ini dilakukan dengan membandingkan signifikansi thitung dengan ketentuan:

a. Jika $\mathrm{t}$ hitung $\leq \mathrm{t}$ tabel pada $\alpha 0.05$, maka Ha ditolak.

b. Jika t hitung $>\mathrm{t}$ tabel pada $\alpha 0.05$, maka Ha diterima. 
4. HASIL DAN PEMBAHASAN

\subsubsection{Corporate Social Responsibility (CSR)}

Menurut Pearce dan Rabinson yang dialih bahasakan oleh Kiroyan (2006:54) mendefinisikan Corporate Social Respponsibility adalah konsep bahwa perusahaan harus melayani masyarakat sosial sebaik memberikan keuntungan financial kepada pemegang saham dan harus berkelanjutan searah terus menerus yang pada akhirnya para manajerakan menyadari bahwa keputusan untuk menerapkan Corporate Social Responsibility adalah keputusan yang sangat penting dalam perencanaan strategis.

Dalam penelitian ini terdapat indikator indikator CSR antara lain :

\section{a. CSR-Ekonomi}

Ekonomi dalam sebuah organisasi mencerminkan kondis dan performa finansial organisasi tersebut. Indikator ekonomi adalah indikator yang digunakan untuk mengukur kondisi perekonomian para pemangku kepentingan di sistem ekonomi lokal, nasional, dan global yang ditimbulkan oleh kinerja suatu perusahaan.

Berikut adalah rumus perhitungan indeks pengungkapan CSR kategori ekonomi (Haniffa et al dalam sayekti dan wondabio, 2007: 13).

$$
\mathrm{CSRDIj}=\frac{\sum \mathrm{Xij}}{n j}
$$

Keterangan:

$\begin{array}{ll}\text { CSRDIJ } & =\text { Corporate } \\ & \text { Responsibility Disclosure Index } \\ & \text { perusahaan } \mathrm{j} \\ \mathrm{Nj} & =\text { Jumlah item untuk perusahaan } \mathrm{j}, \\ & \text { nj untuk indikator ekonomi yaitu } \\ & 9 . \\ & =\text { Dummy variable } 1=\text { jika item } \\ \mathrm{Xij} \quad & \text { diungkapkan, } 0=\text { jika item i tidak } \\ & \text { diungkapkan. }\end{array}$

Tabel 2. Hasil Perhitungan CSREkonomi

\begin{tabular}{|c|c|c|c|c|c|}
\hline \multirow{2}{*}{$\begin{array}{c}\text { Kode } \\
\text { perusahan }\end{array}$} & \multicolumn{5}{|c|}{ Tahun } \\
\cline { 2 - 6 } & $\mathbf{2 0 1 3}$ & $\mathbf{2 0 1 4}$ & $\mathbf{2 0 1 5}$ & $\mathbf{2 0 1 6}$ & $\mathbf{2 0 1 7}$ \\
\hline DSNG & 0,667 & 0,778 & 0,778 & 0,778 & 0,889 \\
\hline LSIP & 0,778 & 0,667 & 0,667 & 0,778 & 0,778 \\
\hline SGRO & 0,667 & 0,556 & 0,556 & 0,556 & 0,556 \\
\hline SIMP & 0,444 & 0,444 & 0,556 & 0,556 & 0,556 \\
\hline SMAR & 0,667 & 0,667 & 0,556 & 0,667 & 0,556 \\
\hline
\end{tabular}

\section{b. CSR-Lingkungan}

Lingkungan adalah kombinasi sumber daya alam yang ada. Indikator lingkungan merupakan indikator yang digunakan untuk mengukur sejauh mana kegiatan organisasi berdampak pada kehidupan di dalam sistem alam, termasuk ekosistem, tanah, dan air. Indikator kinerja lingkungan terkait dengan input (bahan, energi, air) dan output (emisi/gas, limbah sungai, limbah kering /sampah).

Berikut adalah rumus perhitungan indeks pengungkapan CSR kategori lingkungan :

$$
\mathrm{CSRDIj}=\frac{\sum \mathrm{Xij}}{n j}
$$

Keterangan:

$$
\begin{array}{ll}
\text { CSRDIJ } & =\text { Corporate Social Responsibility } \\
& \text { Disclosure Index perusahaan } \mathrm{j} \\
\mathrm{Nj} & =\text { Jumlah item untuk perusahaan } \mathrm{j}, \\
& \text { nj untuk indikator lingkungan } \\
& \text { yaitu } 30 . \\
& =\text { dummy variable } 1=\text { jika item } \\
\text { Xij } \quad \text { diungkapkan, } 0=\text { jika item i tidak } \\
\text { diungkapkan. }
\end{array}
$$

Tabel 3. Hasil Perhitungan CSRLingkungan

\begin{tabular}{|c|c|c|c|c|c|}
\hline \multirow{2}{*}{$\begin{array}{c}\text { Kode } \\
\text { perusahan }\end{array}$} & \multicolumn{5}{|c|}{ Tahun } \\
\cline { 2 - 6 } & $\mathbf{2 0 1 3}$ & $\mathbf{2 0 1 4}$ & $\mathbf{2 0 1 5}$ & $\mathbf{2 0 1 6}$ & $\mathbf{2 0 1 7}$ \\
\hline DSNG & 0,367 & 0,433 & 0,367 & 0,4 & 0,4 \\
\hline LSIP & 0,367 & 0,367 & 0,367 & 0,467 & 0,5 \\
\hline SGRO & 0,467 & 0,483 & 0,533 & 0,567 & 0,533 \\
\hline SIMP & 0,4 & 0,4 & 0,367 & 0,433 & 0,433 \\
\hline SMAR & 0,667 & 0,667 & 0,556 & 0,667 & 0,556 \\
\hline
\end{tabular}




\section{c. CSR-Sosial}

Sosial memiliki arti berkenaan dengan masyarakat. Indikator sosial GRI adalah indikator-indikator yang digunakan untuk mengukur dimensi sosial dari tanggung jawab kerberlanjutan organisai dimana organisasi beroperasi. Indikator kinerja sosial GRI menentukan aspek kinerja penting yang berhubungan dengan ketenagakerjaan, hak asasi manusia, masyarakat dan tanggung jawab produk.

$$
\mathrm{CSRDIj}=\frac{\sum \mathrm{Xij}}{n j}
$$

Keterangan:

CSRDIJ = Corporate Social Responsibility Disclosure Index perusahaan j.

$\mathrm{Nj} \quad=$ Jumlah item untuk perusahaan $\mathrm{j}$, $\mathrm{nj} \quad$ untuk indikator sosial yaitu 40 .

$\mathrm{Xij}=$ dummy variable $1=$ jika item diungkapkan, $0=$ jika item i tidak diungkapkan.

Tabel 4. Hasil Perhitungan CSR-Sosial

\begin{tabular}{|c|c|c|c|c|c|}
\hline \multirow{2}{*}{$\begin{array}{c}\text { Kode } \\
\text { perusahan }\end{array}$} & \multicolumn{5}{|c|}{ Tahun } \\
\cline { 2 - 6 } & $\mathbf{2 0 1 3}$ & $\mathbf{2 0 1 4}$ & $\mathbf{2 0 1 5}$ & $\mathbf{2 0 1 6}$ & $\mathbf{2 0 1 7}$ \\
\hline DSNG & 0,55 & 0,575 & 0,575 & 0,525 & 0,6 \\
\hline LSIP & 0,41 & 0,41 & 0,487 & 0,513 & 0,575 \\
\hline SGRO & 0,467 & 0,25 & 0,2 & 0,2 & 0,275 \\
\hline SIMP & 0,275 & 0,25 & 0,275 & 0,25 & 0,325 \\
\hline SMAR & 0,425 & 0,425 & 0,475 & 0,475 & 0,475 \\
\hline
\end{tabular}

\subsubsection{Profitabilitas (Net Profit Margin)}

Net Profit Margin (NPM), merupakan rasio yang digunakan untuk mengukur

a. Test distribution is Normal.

b. Calculated from data.

c. Lilliefors Significance Correction.

d. This is a lower bound of the true significance.

margin laba atas penjualan, rasio ini akan menggambarkan penghasilan bersih perusahaan berdasarkan total penjualan.

Berikut rumus NPM :

NPM $=\frac{\text { Net Profit After Tax } \times 100 \%}{\text { Net Sales }}$
Keterangan :

Net Profit After Tax = Laba Bersih Setelah Pajak

Net Sales = Penjualan

Tabel 5. Hasil Perhitungan Net Profit Margin (NPM)

\begin{tabular}{|c|c|c|c|c|c|}
\hline \multirow{2}{*}{$\begin{array}{c}\text { Kode } \\
\text { perusahan }\end{array}$} & \multicolumn{5}{|c|}{ Tahun } \\
\cline { 2 - 6 } & $\mathbf{2 0 1 3}$ & $\mathbf{2 0 1 4}$ & $\mathbf{2 0 1 5}$ & $\mathbf{2 0 1 6}$ & $\mathbf{2 0 1 7}$ \\
\hline DSNG & 0,056 & 0,133 & 0,068 & 0,065 & 0,114 \\
\hline LSIP & 0,186 & 0,197 & 0,149 & 0,154 & 0,161 \\
\hline SGRO & 0,047 & 0,105 & 0,083 & 0,152 & 0,08 \\
\hline SIMP & 0,045 & 0,076 & 0,026 & 0,041 & 0,044 \\
\hline SMAR & 0,037 & 0,046 & 0,011 & 0,087 & 0,033 \\
\hline
\end{tabular}

\subsection{Uji Asumsi Klasik \\ 4.2.1 Uji Normalitas}

Uji normalitas dalam penelitian ini menggunakan data nilai residual yang diuji dengan Kolmogorof-Smirnov Test. Uji KolmogorofSmirnov menggunakan bantuan SPSS untuk mngetahui apakah data berdistribusi normal, atau tidak dilihat pada baris Asymph. Sig (2-tailed). Uji normalitas dilakukan dengan melalui pengukuran tingkat signifikansi $5 \%$ atau $\alpha=0,05$.

\section{Tabel 6. Hasil Uji Normalitas}

One-Sample Kolmogorov-Smirnov

Test

\begin{tabular}{|ll|r|}
\hline & & $\begin{array}{r}\text { Unstandardized } \\
\text { Residual }\end{array}$ \\
\hline $\mathrm{N}$ & 25 \\
Normal & Mean & 0 \\
Parameters & Std. & 0,04377423 \\
6 & Deviation & 0,116 \\
Most & Absolute & 0,112 \\
Extreme & Positive & $-0,116$ \\
Differences & Negative & 0,116 \\
Test Statistic & 0,2 \\
Asymp. Sig. (2-tailed) &
\end{tabular}

Sumber: output spss, diolah desember 2018

Berdasarkan pada tabel di atas menyatakan bahwa nilai signifikansi dari fungsi regresi CSR-ekonomi, CSRlingkungan, CSR-sosial, terhadap 
Profitabilitas perusahaan yang diproksikan dengan Net profit Margin (NPM) adalah sebesar 0,200. Nilai tersebut lebih besar dari 0,05 , sehingga dapat disimpulkan bahwa fungsi regresi dari ketiga variabel tersebut telah berdistribusi normal.

\subsubsection{Uji Autokorelasi}

Uji autokorelasi digunakan untuk menguji apakah dalam model regresi linier terdapat korelasi antara kesalahan pengganggu pada periode $t$ dengan kesalahan pada periode t-1 (sebelumnya). Untuk mengetahui ada tidaknya autokorelasi perlu dilakukan pengujian dengan Run test.

Tabel 7. Hasil Uji Autokorelasi

\begin{tabular}{|l|r|}
\hline \multicolumn{2}{|c}{ Runs Test } \\
\hline & $\begin{array}{c}\text { Unstandardized } \\
\text { Residual }\end{array}$ \\
\hline Test Value & \\
Cases $<$ Test & 0,0007 \\
Value & 12 \\
Cases $>=$ Test & 13 \\
Value & 25 \\
Total Cases & 14 \\
Number of Runs & 0,008 \\
Z & 0,993 \\
Asymp. Sig. (2- & \\
tailed) &
\end{tabular}

a. Median

Sumber: output spss, diolah desember 2018

Berdasarkan tabel diatas diketahui nilai Asymp. Sig. (2-tailed) sebesar 0,993 lebih besar > dari 0,05 maka dapat disimpulkan bahwa tidak terdapat autokorelasi karena nilai Asymp. Sig. (2-tailed) lebih besar dari nilai alphanya $(0,05)$.

\subsubsection{Uji Multikolinearitas}

Uji multikolinieritas dalam penelitian ini dilakukan dengan melihat nilai tolerance dan variance inflation factor (VIF). Nilai cut-off yang umum dipakai untuk menunjukkan adanya multikolinieritas adalah nilai tolerance $<0,10$ dan nilai VIF $>10$.
Tabel 8. Hasil Uji Multikolinearitas

\begin{tabular}{|c|c|c|c|c|c|c|c|c|}
\hline & & \multicolumn{7}{|c|}{ Coefficients $^{2}$} \\
\hline \multirow{2}{*}{\multicolumn{2}{|c|}{ Model }} & \multicolumn{2}{|c|}{\begin{tabular}{c|}
$\begin{array}{c}\text { Unstandardized } \\
\text { Coefficients }\end{array}$ \\
\end{tabular}} & \multirow{2}{*}{\begin{tabular}{|c|}
$\begin{array}{c}\text { Standardized } \\
\text { Coefficients }\end{array}$ \\
Beta
\end{tabular}} & \multirow{2}{*}{ t } & \multirow{2}{*}{ Sig. } & \multicolumn{2}{|c|}{$\begin{array}{c}\text { Collinearity } \\
\text { Statistics }\end{array}$} \\
\hline & & B & \begin{tabular}{|c|} 
Std. \\
Error
\end{tabular} & & & & Tolerance & VIF \\
\hline \multirow[t]{4}{*}{1} & (Constant) & 0,112 & 0,096 & & 1,162 & 0,258 & & \\
\hline & $\begin{array}{l}\text { CSR. } \\
\text { ekronomi }\end{array}$ & 0,242 & 0,133 & 0,507 & 1,816 & 0,084 & 0,385 & 2,596 \\
\hline & $\begin{array}{l}\text { CSR- } \\
\text { linghungan }\end{array}$ & $-0,319$ & 0,139 & $-0,41$ & $-2,288$ & 0,033 & 0,934 & 1,071 \\
\hline & CSR-sosial & $-0,092$ & 0,112 & $-0,227$ & $.0,823$ & 0,42 & 0,396 & 2,525 \\
\hline
\end{tabular}

Sumber: output spss, diolah desember 2018

Berdasarkan tabel di atas hasil perhitungan nilai tolerance menunjukkan bahwa tidak ada variabel independen yang memiliki nilai tolerance $<0,10$ dan tidak ada nilai VIF > 10. Dapat dilihat dari CSRekonomi memiliki nilai tolerance sebesar 0,385 dan nilai VIF sebesar 2,596, CSR-

lingkungan memiliki nilai tolerance sebesar 0,934 dan nilai VIF sebesar 1,071, CSRsosial memliki nilai tolerance sebesar 0,396 dan nilai VIF sebesar 2,525. Hal ini dapat disimpulkan bahwa model regresi dalam penelitian ini tidak terjadi multikolinearitas dan model regresi layak digunakan.

\subsubsection{Uji Heteroskedastisitas}

Untuk mendeteksi ada tidaknya heteroskedastisitas dalam penelitian ini digunakan Uji Park Gleyser dengan cara mengkorelasikan nilai absolute residualnya dengan masing-masing variabel independen. Jika hasil nilai probabilitasnya memiliki nilai signifikansi > nilai alphanya $(0,05)$, maka model tidak mengalami heteroskedastisitas.

Tabel 9. Hasil Uji Heterokedastisitas

Coefficients $^{2}$

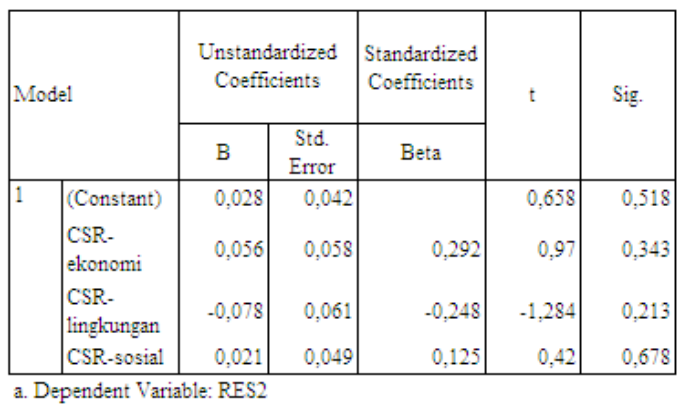

Sumber: output spss, diolah desember 2018 
Berdasarkan uji Park Gleyser yang telah dilakukan, jika dilihat dari koefisien parameter untuk masing-masing variabel independen tidak ada yang signifikan karena nilai signifikan di atas 0,05. Ditunjukkan dari nilai signifikan CSRekonomi sebesar 0,343, nilai signifikan CSR-lingkungan sebesar 0,213 dan nilai signifikan CSR-sosial sebesar 0,678, artinya masing-masing nilai signifikan dari variabel independen lebih dari 0,05 . Hal ini dapat disimpulkan bahwa model regresi yang digunakan tidak terdeteksi heteroskedastisitas.

\subsection{Analisis Uji Regresi Linier Berganda}

Analisis regresi linier berganda digunakan untuk mengetahui pengaruh Corporate Social Responsibility (CSR) terhadap profitabilitas perusahaan yang dimana variabel independen CSR berupa indikator CSR-ekonomi, CSR-lingkungan, CSRsosial dan untuk variabel dependen diproksikan dengan Net Profit Margin (NPM).

Tabel 10. Hasil Uji Regresi Linier Berganda

\begin{tabular}{|c|c|c|c|c|c|c|}
\hline \multicolumn{7}{|c|}{ Coefficients $^{2}$} \\
\hline \multirow{2}{*}{\multicolumn{2}{|c|}{ Model }} & \multicolumn{2}{|c|}{$\begin{array}{l}\text { Unstandardized } \\
\text { Coefficients }\end{array}$} & \multirow{2}{*}{\begin{tabular}{|c|}
$\begin{array}{c}\text { Standardized } \\
\text { Coefficients }\end{array}$ \\
Beta \\
\end{tabular}} & \multirow[t]{2}{*}{ t } & \multirow[t]{2}{*}{ Sig. } \\
\hline & & B & Std. Error & & & \\
\hline \multirow[t]{4}{*}{1} & (Constant) & 0,112 & 0,096 & & 1,162 & 0,258 \\
\hline & $\begin{array}{l}\text { CSR- } \\
\text { ekonomi }\end{array}$ & 0,242 & 0,133 & 0,507 & 1,816 & 0,084 \\
\hline & $\begin{array}{l}\text { CSR- } \\
\text { lingkungan }\end{array}$ & $-0,319$ & 0,139 & $-0,41$ & $-2,288$ & 0,033 \\
\hline & CSR-sosial & $-0,092$ & 0,112 & $-0,227$ & $-0,823$ & 0,42 \\
\hline
\end{tabular}

Sumber: output spss, diolah desember 2018

Berdasarkan hasil analisis regresi seperti tertera pada table diatas dapat disusun persamaan regresi sebagai berikut: PROF $=0,112+0,242 \beta 1-0,391 \beta 2-$ $0,092 \beta 3+e$

\subsection{Uji Hipotesis \\ 4.4.1 Koefisien Determinasi}

Hasil nilai $R$-Square dari regresi di gunakan untuk menjelaskan besarnya struktur model yang dipengaruhi oleh variabel independennya.

Tabel 11. Hasil Uji Koefisien Determinasi

\begin{tabular}{|r|r|r|r|c|}
\multicolumn{5}{|c}{ Model Summary } \\
\hline Model & $\mathrm{R}$ & R Square & $\begin{array}{c}\text { Adjusted } \\
\mathrm{R} \\
\text { Square }\end{array}$ & $\begin{array}{c}\text { Std. } \\
\text { Error of } \\
\text { the } \\
\text { Estimate }\end{array}$ \\
\hline 1 &, $607^{\mathrm{a}}$ & 0,369 & 0,279 & 0,046797 \\
\hline
\end{tabular}

a. Predictors: (Constant), CSR-sosial, CSR-lingkungan, CSR-ekonomi

Sumber: output spss, diolah desember 2018

Berdasarkan tabel diatas diperoleh angka R2 ( $R$ Square) sebesar 0,369 atau $36,9 \%$. Hal ini menunjukkan bahwa variabel independen CSR-ekonomi, CSRlingkungan, dan CSR-sosial menjelaskan variabel dependen yaitu profitabilitas (NPM) perusahaan sebesar 36,9\% sedangkan sisanya $63,1 \%$ menjelaskan oleh variabel lain yang tidak dimasukkan dalam model yang diajukan dalam penelitian ini.

\subsubsection{Uji F (Uji Silmutan)}

Uji F (uji simultan) digunakan untuk mengetahui apakah semua variabel independen CSR-ekonomi, CSRlungkungan, dan CSR-sosial yang dimasukkan dalam persamaan atau model regresi secara simultan berpengaruh terhadap variabel dependen Net Profit Margin (NPM). Uji F dilakukan dengan cara membandingkan antara nil nilai F-tabel dengan nilai F-hitung yang terdapat pada tabel ANOVA.

\section{Tabel 12. Hasil Uji F (Uji Silmutan)}

\begin{tabular}{|c|c|c|c|c|c|c|}
\hline \multicolumn{7}{|c|}{ ANOVA $^{2}$} \\
\hline \multicolumn{2}{|c|}{ Model } & $\begin{array}{l}\text { Sum of } \\
\text { Souares }\end{array}$ & $d f$ & $\begin{array}{l}\text { Mean } \\
\text { Soure }\end{array}$ & F & Sig. \\
\hline \multirow[t]{3}{*}{1} & Regression & 0,027 & 3 & 0,009 & 4,088 &, $020^{\circ}$ \\
\hline & Residual & 0,046 & 21 & 0,002 & & \\
\hline & Total & 0,073 & 24 & & & \\
\hline
\end{tabular}


Sumber: output spss, diolah desember 2018

Berdasarkan pada tabel di atas menunjukkan bahwa nilai F-hitung adalah sebesar 4.088 dengan nilai Sig. sebesar 0,020. Nilai F-tabel dengan tingkat signifikan atau $\alpha=5 \%$ dan $\mathrm{df}=(4-1) ;(25$ $3)=3 ; 22$ sebesar 3,05. Nilai sig 0,020 < 0,05 sehingga dapat diartikan bahwa ketiga variabel tersebut signifikan. Nilai F-hitung lebih besar dari pada nilai F-tabel atau 4,088> 3,05 maka dapat disimpulkan bahwa variabel independen yaitu CSRekonomi, CSR-lingkungan, dan CSR-sosial berpengaruh secara simultan terhadap variabel dependen yaitu profitabilitas perusahaan dengan demikian $\mathrm{Ha}_{4}$ diterima dan $\mathrm{H}_{0}$ ditolak. Hasil uji $\mathrm{F}$ ini sejalan dengan penelitian Sitorus dan Mangoting (2014) yang mebahas tentang CSR berseta indikator-indikator yang terdapat dalam CSR global reporting initiative.

\subsubsection{Uji t (Uji Parsial)}

Uji T (uji parsial) digunakan untuk mengetahui seberapa jauh pengaruh variabel independen CSR-ekonomi CSRlingkungan CSR-sosial secara parsial terhadap variabel dependennya yaitu profitabilitas perusahaan. Uji $\mathrm{T}$ dilakukan dengan cara membandingkan T-hitung dengan $\mathrm{T}$-tabel dengan tingkat signifikan $(\alpha)$ yaitu sebesar $5 \%$ dan degree of freedom (df) $=\mathrm{n}-\mathrm{k}$ untuk menentukan besarnya nilai T-tabel sebagai batas daerah penerimaan/penolakan hipotesis.

\section{Tabel 13. Hasil Uji t (Uji Parsial)}

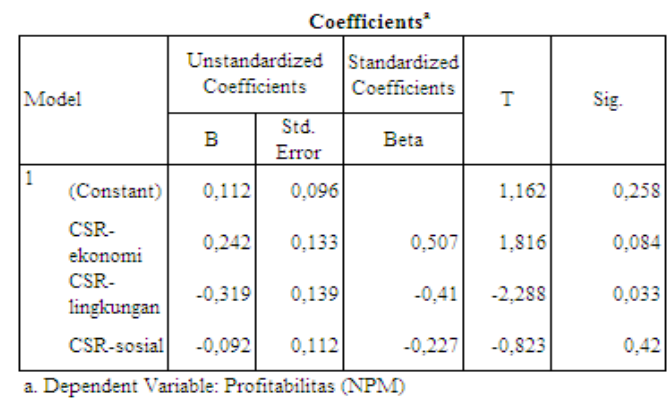

Sumber: output spss, diolah desember 2018
Berdasarkan pada tabel di atas menunjukan CSR-ekonomi $\left(\mathrm{X}_{1}\right)$ terhadap profitabilitas (Y). Terlihat pada kolom coefficients model 1 terdapat nilai sig 0,084 . Nilai sig lebih besar dari nilai $(\alpha)$ yaitu sebesar 0,05 atau nilai $0,084>0,05$ maka $\mathrm{Ha}_{1}$ ditolak dan $\mathrm{H}_{0}$ diterima. Hal ini dapat dilihat bahwa CSR-ekonomi tidak berpengaruh signifikan terhadap Net Profit Margin (NPM). CSR-lingkungan $\left(\mathrm{X}_{2}\right)$ terhadap profitabilitas $(\mathrm{Y})$. Terlihat pada kolom coefficients model 1 terdapat nilai sig 0,033 . Nilai sig lebih kecil dari nilai $(\alpha)$ yaitu sebesar 0,05 atau nilai $0,033<0,05$ maka $\mathrm{Ha}_{2}$ diterima dan $\mathrm{H}_{0}$ ditolak. Hal ini dapat dilihat bahwa CSR-lingkungan tidak pengaruh signifikan terhadap Net Profit Margin (NPM). CSR-sosial $\left(\mathrm{X}_{3}\right)$ terhadap profitabilitas (Y). Terlihat pada kolom coefficients model 1 terdapat nilai sig 0,420 . Nilai sig lebih besar dari nilai $(\alpha)$ yaitu sebesar 0,05 atau nilai $0,420>0,05$ maka $\mathrm{Ha}_{3}$ ditolak dan $\mathrm{H}_{0}$ diterima. Hal ini dapat dilihat bahwa CSR-sosial tidak berpengaruh signifikan terhdap Net Profit Margin (NPM).

\section{KESIMPULAN DAN SARAN}

\subsection{Kesimpulan}

Dari penelitian ini maka dapat di simpulkan bahwa :

1. Hasil pengujian hipotesis pertama $\left(\mathrm{Ha}_{1}\right)$ menunjukkan bahwa variabel CSR-ekonomi tidak berpengaruh terhadap profitabilitas perusahaan atau $\mathrm{Ha}_{1}$ ditolak.

2. Hasil pengujian hipotesis kedua $\left(\mathrm{Ha}_{2}\right)$ menunjukkan bahwa variabel CSRlingkungan berpengaruh terhadap profitabilitas perusahaan atau $\mathrm{Ha}_{2}$ diterima.

3. Hasil pengujian hipotesis ketiga $\left(\mathrm{Ha}_{3}\right)$ menunjukkan bahwa variabel CSRsosial tidak berpengaruh terhadap profitabilitas perusahaan atau $\mathrm{Ha}_{3}$ ditolak. 
4. Hasil pengujian hipotesis keempat $\left(\mathrm{Ha}_{4}\right)$ menunjukkan bahwa variabel CSR-ekonomi, CSR-lingkungan, dan CSR-sosial berpengaruh terhadap profitabilitas perusahaan atau $\mathrm{Ha}_{4}$ diterima.

\subsection{Saran}

Saran untuk Penelitian selanjutnya diharapkan menggunakan populasi selain perusahaan di sektor perkebunan sehingga dapat memperoleh sampel yang lebih banyak. Peneliti selanjutnya diharapkan mengikuti perkembangan dan memperbarui item-item yang digunakan dalam menilai pengungkapan CSR.

\section{DAFTAR PUSTAKA}

Achda, B Taman. 2007. Konteks Sosiologi Perkembangan Corporate Sosial Responsibility dan Implementasinya Di Indonesia.

A. Zeithaml, V. Parasuraman, A. and L. Berry L. 1985. "Problems and Strategies in Services Marketing". Jurnal of Marketing Vol. 49. (Spring).

Ardianto, Elvinaro, dkk. 2009. Komunikasi Massa Suatu Pengantar Edisi Revisi. Bandung: Simbiosa Rekatama Media.

Astuti, Dewi, 2004. Manajemen Keuangan Perusahaan, Cetakan Pertama, Ghalia Indonesia, Jakarta.

Beny.B. 2012. Corporate Social Responsibility.San Fransisco.

Brigham Eugene, F. dan J. Houston. 2004. Fundamentals of Financial Management Dasar-dasar Manajemen Keuangan. Edisi 10. Buku 2. Jakarta:

Daniri, 2008, "Standardisasi Tanggung Jawab Sosial Perusahaan", Jakarta: Gramedia Pustaka Utama.

Darsono dan Ashari. 2005. Pendoman Praktis Memahami Laporan Keuangan. Jakarta: Salemba Empat.

Darwin, Ali. 2004. Penerapan Sustainability Reporting di Indonesia. Konvensi Nasional Akuntansi V, Program Profesi
Lanjutan, Yogyakarta, 13-15

Desember.

Fahmi. Irham. 2011. Analisa Laporan Keuangan. Bandung: Alfabeta.

Ghozali, Imam. 2012. Aplikasi Analisis Multivariate dengan Program IBM SPSS. Yogyakarta: Universitas Diponegoro.

Gray, et. al. 1995. Corporate Social and Environmental Reporting: A Review of Literature and a Longitudinal Study of UK Disclosure. Accounting, Audiitng, and Accountability Journal, Vol.8 No 2: 47-76.

GRI. (2012). Sustainability Reporting Guidelines G3. Diambil dari https://www.globalreporting.org/, pada tanggal 29 September 2009.

Sugiyono. 2015. Metode Penelitian Pendidikan (Pendekatan Kuantitatif, Kualitatif dan R\&D). Penerbit CV. Alfabeta: Bandung.

Sugiono Arif dan Edi Untung. 2008. Panduan Praktis Dasar Analisa laporan keuangan. Grasindo. Jakarta.

Undang-Undang Nomor 40 pasal 74 tentang Perseroan terbatas. Jakarta. 2007.

Undang-Undang Nomor 25 tahun tentang penanaman modal. Jakarta. 2007. 